\title{
Effect of Solid-state Fermentation on the Nutritional Composition of Nettle (Urtica dioica L.) $)^{\#}$
}

\author{
Emrah Güngör ${ }^{1, a, *}$, Aydın Altop ${ }^{1, b}$, Güray Erener ${ }^{1, c}$ \\ ${ }^{1}$ Department of Animal Science, Faculty of Agriculture, Ondokuz Mayls University, 55139 Samsun, Turkey
}

*Corresponding author

\begin{tabular}{|c|c|}
\hline A R T I C L E I N F O & A B S T R A C T \\
\hline $\begin{array}{l}\text { "This study was presented as an oral } \\
\text { presentation at the } 1^{\text {st }} \text { International } \\
\text { Congress of the Turkish Journal of } \\
\text { Agriculture - Food Science and } \\
\text { Technology (Antalya, TURJAF 2019) } \\
\text { Research Article } \\
\text { Received : } 17 / 11 / 2019 \\
\text { Accepted : } 01 / 12 / 2019\end{array}$ & $\begin{array}{l}\text { The study was aimed to improve the nutritional composition of nettle (Utrica dioica L.) having } \\
\text { positive effects on animals by solid-state fermentation. Aspergillus niger was used as a inoculant in } \\
\text { fermentation of nettle. Before and after fermentation, crude protein (CP), ash, ether extract (EE), } \\
\text { nitrogen-free extract (NFE), crude fiber (CF), hemicellulose (HC), neutral detergent fiber (NDF), } \\
\text { acid detergent fiber (ADF) and acid detergent lignin (ADL) contents of nettle were determined. The } \\
\text { ash, NFE and HC content of nettle were increased by fermentation. However, A. niger decreased the } \\
\text { CF and EE in nettle. The results showed that solid-state fermentation with A. niger can be used to } \\
\text { improve the nutritional composition of nettle. }\end{array}$ \\
\hline
\end{tabular}

Keywords:

Aspergillus niger

Nettle

Nutritional enrichment

Solid-state fermentation

Utrica dioica $\mathrm{L}$.

\section{Introduction}

Herbs and herbal products have been used as food with medicinal purposes for centuries. Nettle (Utrica dioica L.) is widely grown in different parts of the world and has been used to improve human health. Nettle contains some phenolic compounds such as carvacrol and thymol (Bakır, 2018). These phenolic compounds have immunestimulatory, anti-carcinogenic, anti-inflammatory, antioxidant, antimicrobial and antiallergenic properties (Safamehr et al., 2012).

Nettle contains $21-23 \%$ crude protein and $9-21 \%$ crude fiber (Zehraw et al., 2019). Researchers have focused on nettle as a feed additive in generally poultry nutrition. Nettle increased body weight and feed conversion ratio in broiler chickens (Safamehr et al., 2012) and has positive effects on egg production of laying hens (Mansoub, 2011). It also reduced serum triglyceride and cholesterol in broilers (Safamehr et al., 2012) and laying hens (Mansoub,
2011). Moreover, nettle improved the yellowness of the skin, liver (Loetscher et al., 2013a) and egg yolk (Loetscher et al., 2013b). Although nettle has positive effects on poultry, it can be used limited levels in poultry diets due to its high crude fiber (CF) content, which can be up to $21 \%$.

Fermentation is one of the useful methods for recycling the agricultural by-products by enriching its nutritional composition. Fermentation is generally divided into liquidstate and solid-state fermentation. Solid-state fermentation is the preferred method for liquid-state fermentation because of being economical, using abundant and cheap substrates in and having relatively less risk of contamination. Solid-state fermentation refers to microbial growth in moistened solid substances without free water (Güngör et al., 2017). Agricultural residues can be enriched as nutritional content by solid-state fermentation (Gungor and Erener, 2019). Wang et al. (2018) reported increased 
crude protein $(\mathrm{CP})$ and decreased $\mathrm{CF}$ in Moringa oleifera leaves by fermentation. Similarly, fermentation improved the amino acid composition of olive leaves (Altop et al., 2018a). Aspergillus niger is a recommended microorganism for solid-state fermentation because it can grow rapidly in low-water environments. It is also used as a probiotic in animal nutrition and is accepted as "Generally Recognized as Safe" (GRAS) by the US Food and Drug Administration (FDA, Güngör et al., 2017). This study aimed to improve the nutritional composition of nettle by $A$. niger solid-state fermentation.

\section{Materials and Methods}

\section{Solid-State Fermentation}

The study was conducted in the Laboratory of Feeds and Animal Nutrition in the Department of Animal Science at Ondokuz Mayis University, Turkey. Nettle was harvested and dried at room temperature. Aspergillus niger was obtained from American Type Culture Collection (ATCC) and left in incubation in Potato-Dextrose-Agar on $28^{\circ} \mathrm{C}$ for 7 days according to agar plate technique. After incubation, A. niger spores were harvested by turning the plate upside down and gently hitting the top. Spore counting was conducted according to Fuch Rosenthal technique using a hematocytometer. Dried nettle was ground to a size of $1 \mathrm{~mm}$ and sterilized at $121^{\circ} \mathrm{C}$ for 15 minutes. Samples were enriched by Potato Dextrose Broth (150 $\mathrm{ml}$ for each 100 gram sample). Aspergillus niger spores $\left(10^{6}\right.$ spores $\left./ \mathrm{ml}\right)$ were inoculated the samples in the sterile cabin and left incubation for 7 days at $28-30{ }^{\circ} \mathrm{C}$ according to Gungor and Erener (2019).

\section{Chemical Composition and Nutrient Values}

The CP, ether extract (EE), ash, and CF contents of CK were determined according to AOAC (2000). Neutral detergent fiber (NDF) and acid detergent fiber (ADF) were analyzed as reported by Van Soest et al. (1991). Hemicellulose (HC) was calculated as NDF minus ADF. Nitrogen-free extract (NFE) was estimated on a dry weight basis by subtracting the percentages of $\mathrm{CP}, \mathrm{EE}, \mathrm{CF}$ and ash from $100 \%$.

\section{Statistical Analysis}

Experiments were conducted in triplicate and the results were given as means and pooled standard error of mean (SEM). Data were analyzed with Student's t-test (SPSS 21.0 Statistics, IBM, 2012). Results were considered significantly different at $\mathrm{P}<0.05$.

\section{Results and Discussion}

Aspergillus niger increased the ash $(\mathrm{P}<0.001)$, NFE $(\mathrm{P}<0.001)$ and $\mathrm{HC}(\mathrm{P}<0.05)$ content of nettle but decreased the $\mathrm{CF}(\mathrm{P}<0.001)$ and $\mathrm{EE}(\mathrm{P}<0.05)$ content (Table 1$)$. The $\mathrm{CP}, \mathrm{NDF}, \mathrm{ADF}$ and $\mathrm{ADL}$ content were not changed ( $\mathrm{P}>0.05)$ by the solid-state fermentation.

Altop (2019) reported increased ash content in olive leaves similar to the findings of the present study. Fermentation also increased the ash content of pomegranate peel and Larrea tridentate leaves (Aguilar et al., 2008), cassava peels (Okpako et al., 2008) and pineapple waste (Omwango et al., 2013). The increase in ash content possibly was relative due to decrease in other nutrients rather than actual increase.

Microorganisms preferred soluble carbohydrates to other nutrients for using a carbon source (Papagianni, 2007). Vandenberghe et al. (2000) noted that the NFE content of cassava bagasse was decreased by solid-state fermentation. Similar findings were reported by the studies on olive leaves (Altop et al., 2018a) cassava peels (Aro, 2008; Okpako et al., 2008) and grape seed (Altop et al., 2018b). However, Altop (2019) reported no effect of solidstate fermentation on the nutritional composition of olive leaves. Aspergillus niger increased the NFE content of nettle in this study. Similarly, Apata (2011) showed increased NFE in Terminalia catappa fruit meal by $A$. niger.

Güngör et al. (2017) reported decreased EE content by A. niger in sour cherry kernel. In the present study, nettle showed lower EE content after fermentation. Similar findings were reported in the studies on T. catappa (Apata, 2011), mango kernel (Kayode and Sani, 2008), grape seed (Altop et al., 2018b) and sour cherry kernel (Güngör et al., 2017). Decreasing of the ether extract content may be due to the lipase enzymes which can be produced by A. niger in solid-state fermentation (Kumar and Kanwar, 2012).

Aspergillus niger can increase the CP content of the substrates may be owing to its mycelia and/or producing enzymes (Güngör et al., 2017). Enrichment in CP content by fermentation was reported in the studies on M. oleifera leaves (Wang et al., 2018), pomegranate peels and L.tridentata leaves (Aguilar et al., 2008), Ginkgo biloba leaves (Zhang et al., 2013; Zhao et al., 2013) and sour cherry kernel (Gungor and Erener, 2019). However, there is no change in CP content between of unfermented and fermented nettle. This may be due to changes in the ratios of the other nutrients in the nettle. Similarly, Altop et al. (2019) reported no changed CP level in cottonseed meal by A. niger solid-state fermentation.

Table 1 Nutritional composition of unfermented nettle (N) and fermented nettle (FN)

\begin{tabular}{l|cccc}
\hline \multicolumn{1}{c|}{ Composition (\% DM) } & $\mathrm{N}$ & $\mathrm{FN}$ & $\mathrm{SEM}$ & $\mathrm{P}$ \\
\hline Crude protein & 23.19 & 24.27 & 0.339 & $\mathrm{NS}$ \\
Ether extract & 2.46 & 1.40 & 0.260 & $*$ \\
Ash & 20.24 & 24.12 & 0.878 & $* * *$ \\
NFE & 21.19 & 30.75 & 2.153 & $* * *$ \\
Crude fiber & 32.93 & 19.45 & 3.018 & $* * *$ \\
NDF & 38.85 & 37.99 & 0.956 & $\mathrm{NS}$ \\
ADF & 29.15 & 25.53 & 1.288 & $\mathrm{NS}$ \\
ADL & 9.40 & 10.73 & 0.909 & $\mathrm{NS}$ \\
Hemicellulose & 9.71 & 12.46 & 0.702 & $*$ \\
\hline
\end{tabular}

*: $\mathrm{P}<0.05, * * *: \mathrm{P}<0.001, \mathrm{NS}$ : Not significant, NFE: nitrogen-free extract, SEM: standard error of means 
Structural carbohydrates such as cellulose, hemicellulose and lignin reduce the nutrient digestibility in feeds because they are difficult to digest by animals (Graminha et al., 2008). Therefore, the structural carbohydrate level of the feed is an important indicator for the estimation of feed digestibility. Aspergillus niger decreased the CF content of nettle by solid-state fermentation in this study. Similar results were taken from the studies on M. oleifera leaves (Wang et al., 2018), olive leaves (Altop, 2019), pineapple waste (Omwango et al., 2013) and cassava peel (Aro, 2008). Xie et al. (2016) showed that $A$. niger can produce the cellulase enzyme during fermentation. Reduction in the CF of nettle by fermentation can be attributed to the cellulose enzymes which is possibly produced by A. niger during fermentation processes.

\section{Conclusions}

The results of the present study showed that A. niger changed the nutritional composition of nettle by increasing ash, NFE and HC content and decreasing EE and CF content. Fermentation can be used to increase the inclusion level of nettle to poultry diets. Further studies are needed to confirm the usability of fermented nettle in poultry nutrition.

\section{References}

Aguilar CN, Aguilera-Carbo A, Robledo A, et al. 2008. Production of antioxidant nutraceuticals by solid-state cultures of pomegranate (Punica granatum) peel and creosote bush (Larrea tridentata) leaves. Food Technol Biotechnol, 46(2):218-22.

Altop A. 2019. Effect of solid-state fermentation on main nutritional components, some minerals, condensed tannin and phenolic compounds of olive leaves. Turkish Journal of Agriculture-Food Science and Technology, 7(1):115-9.

Altop A, Coskun I, Filik G, et al. 2018a. Amino acid, mineral, condensed tannin, and other chemical contents of olive leaves (Olea europaea L.) processed via solid-state fermentation using selected Aspergillus niger strains. Ciencia e Investigación Agraria, 45(3):220-30.

Altop A, Güngör E, Erener G. 2018b. Aspergillus niger may improve nutritional quality of grape seed and its usability in animal nutrition through solid-state fermentation. International Advanced Researches and Engineering Journal, 2(3):273-7.

Altop A, Güngör E, Erener G. 2019. Improvement of nutritional quality of some oilseed meals through solid-state fermentation using Aspergillus niger. Turkish Journal of Agriculture-Food Science and Technology, 7(9):1411-4.

AOAC. 2000. Official methods of analysis of AOAC International (17th edition). Place of publication: ABD: AOAC International.

Apata DF. 2011. Effect of Terminalia catappa fruit meal fermented by Aspergillus niger as replacement of maize on growth performance, nutrient digestibility, and serum biochemical profile of broiler chickens. Biotechnology Research International, 2011:1-6.

Aro S. 2008. Improvement in the nutritive quality of cassava and its by-products through microbial fermentation. African Journal of Biotechnology, 7(25):4789-97.

Bakır TK. 2018. Investigation of Oxidation Rate Relationship Between Fatty Acid Contents of St. John's Wort (Hypericum perforatum) Oil and Nettle (Urtica dioica) Seed Oil. Turkish Journal of Agriculture-Food Science and Technology, 6(11):1647-52.
Graminha E, Gonçalves A, Pirota R, Balsalobre M, Da Silva R, Gomes E. 2008. Enzyme production by solid-state fermentation: Application to animal nutrition. Anim Feed Sci Technol, 144(1):1-22.

Gungor E, Erener G. 2019. Effect of dietary raw and fermented sour cherry kernel (Prunus cerasus L.) on growth performance, carcass traits, and meat quality in broiler chickens. Poultry Science.

Güngör E, Altop A, Öztürk E, Erener G. 2017. Nutritional changes of sour cherry (Prunus cerasus) kernel subjected to Aspergillus niger solid-state fermentation. Journal of Tekirdag Agricultural Faculty, The Special Issue of 2nd International Balkan Agriculture Congress:99-103.

IBM. 2012. IBM SPSS Statistics for Windows, Version 21.0. IBM Corp., Armonk, NY. Place of publication.

Kayode R, Sani A. 2008. Physicochemical and proximate composition of mango (Mangifera indica) kernel cake fermented with mono-culture of fungal isolates obtained from naturally decomposed mango kernel. Life Science Journal, 5(4):55-63.

Kumar A, Kanwar SS. 2012. Lipase production in solid-state fermentation (SSF): recent developments and biotechnological applications. Dynamic Biochemistry, Process Biotechnology and Molecular Biology, 6(1):13-27.

Loetscher Y, Kreuzer M, Messikommer R. 2013a. Oxidative stability of the meat of broilers supplemented with rosemary leaves, rosehip fruits, chokeberry pomace, and entire nettle, and effects on performance and meat quality. Poultry Science, 92(11):2938-48.

Loetscher Y, Kreuzer M, Messikommer R. 2013b. Utility of nettle (Urtica dioica) in layer diets as a natural yellow colorant for egg yolk. Animal Feed Science and Technology, 186(3-4):158-68.

Mansoub NH. 2011. Effect of nettle (Urtica dioica) on performance, quality of eggs and blood parameters of laying hens. Advances in Environmental Biology, 5(9):2718-21.

Okpako C, Ntui V, Osuagwu A, Obasi F. 2008. Proximate composition and cyanide content of cassava peels fermented with Aspergillus niger and Lactobacillus rhamnosus. J Food Agric Environ, 6(2):251-5.

Omwango EO, Njagi ENM, Orinda GO, Wanjau RN. 2013. Nutrient enrichment of pineapple waste using Aspergillus niger and Trichoderma viride by solid state fermentation. African Journal of Biotechnology, 12(43):6193-6.

Papagianni M. 2007. Advances in citric acid fermentation by Aspergillus niger: biochemical aspects, membrane transport and modeling. Biotechnol Adv, 25(3):244-63.

Safamehr A, Mirahmadi M, Nobakht A. 2012. Effect of nettle (Urtica dioica) medicinal plant on growth performance, immune responses, and serum biochemical parameters of broiler chickens. International Research Journal of Applied and Basic Sciences, 3(4):721-8.

Van Soest Pv, Robertson J, Lewis B. 1991. Methods for dietary fiber, neutral detergent fiber, and nonstarch polysaccharides in relation to animal nutrition. J Dairy Sci, 74(10):3583-97.

Vandenberghe LP, Soccol CR, Pandey A, Lebeault J-M. 2000. Solid-state fermentation for the synthesis of citric acid by Aspergillus niger. Bioresour Technol, 74(2):175-8.

Wang J, Cao F, Zhu Z, Zhang X, Sheng Q, Qin W. 2018. Improvement of quality and digestibility of Moringa oleifera leaves feed via solid-state fermentation by Aspergillus niger. International Journal of Chemical Reactor Engineering, 16(12):1-14.

Xie P, Huang L, Zhang C, Zhang Y-1. 2016. Nutrient assessment of olive leaf residues processed by solid-state fermentation as an innovative feedstuff additive. J Appl Microbiol, 121(1):28-40.

Zehraw HM, Taleb ZMM, Mukhlif B, Al-Jabbar SA. 2019. Extraction and evaluation the activity of Urtica dioica as bleeding stop material. Iraqi Journal of Biotechnology, 18(2). 
Zhang X, Zhao L, Cao F, Ahmad H, Wang G, Wang T. 2013. Effects of feeding fermented Ginkgo biloba leaves on small intestinal morphology, absorption, and immunomodulation of early lipopolysaccharide-challenged chicks. Poult Sci, 92(1):119-30.
Zhao L, Zhang X, Cao F, Sun D, Wang T, Wang G. 2013. Effect of dietary supplementation with fermented Ginkgo-leaves on performance, egg quality, lipid metabolism and egg-yolk fatty acids composition in laying hens. Livest Sci, 155(1):7785 . 